\title{
Trading Activities and Cross-Sectional Variation in Stock Expected Return: Evidence from Kuala Lumpur Stock Exchange
}

\author{
Huson Joher Ali Ahmed \\ School of Accounting, Finance and Economics, Deakin University \\ Victoria, 3217, Australia \\ Tel: 614-5842-4559Ｅ-mail: huson.aliahmed@deakin.edu.au
}

\begin{abstract}
The publication fee for this paper was funded from RPI point, Curtin University of Technology, Sarawak Malaysia Campus
\end{abstract}

The author greatly acknowledges enormous comments from Australasian Banking and Finance conference, December, 2003

\begin{abstract}
Trading activity has been considered as one of the possible factor that explains the cross-sectional variation in stock returns. In this study I use trading volume as a possible measure to proxy for liquidity as part of the trading activity. Monthly observations were used over a period 1995 to 2005 to examine the liquidity effect on stock expected returns. Based on findings it is appeared that level of liquidity does matter in explaining the expected stock returns in Malaysian capital market. While Fama-french factors also provide important explanation for stock returns. But none of the second moment variables proxying liquidity appeared to be statistically significant. However, momentum effect apprearently explaining the cross-sectional variation in stock returns.
\end{abstract}

Keywords: Liquidity, Expected returns, Momentum effect, Fama-French factor

\section{Introduction on liquidity and trading activities}

The issue on predictability of expected returns has been important topics and on going debate among academics and researchers alike due to its strategic implication for both individual and portfolio investors. Efficient market postulates that, investors may not be able to use price related information to predict the stock returns. The finance literature on predictability of asset returns goes back at least early 1950s starting with Markowitz's Mean-variance efficiency and capital asset pricing model (1963) and arbitrage pricing theory (1973) and multifactor model was in its latest development. All these models have been developed to provide an economic rational for the formation of the asset price with the concept of equilibrium.

However, in recent years, there other school of thoughts which posits that the price formation could have been the result of the market micro-structure (trading activities and market liquidity). This adds new frontiers in the finance literature that provide further avenue to examine asset pricing beyond traditional equilibrium asset pricing concept. Finance theory defines liquidity as the ability to buy or sell large quantities of asset quickly by incurring lower cost. Liquidity of the stock could be served as a good barometer for the proper functioning of a market as it measures the degree of easiness with which stock can be traded. If liquidity were to be an important factor in pricing financial securities, portfolio investors should be much more concern about the magnitude of the liquidity of the market as this might have greater impact on their portfolio returns. Should the market be fairly efficient, small player can easily enter and exit the market while big portfolio investors may feel they are restricted as they are being tied with huge sum of investment.

In security industry, portfolio managers and investment consultants tailor portfolio to meet to their clients' investment horizon and liquidity objective. Hence liquidity influences the very objective of the portfolio decision. Therefore, proper proxy measures are needed to reflect the liquidity of the market. Numerous measures have been in the past to proxy for liquidity. These are trading volume, trading turnover \& bid-ask spread, market depth and many others. Generally liquidity measure can be divided two, namely friction and activity. A friction measure is defined as the price concession for immediacy or trading cost. It can be sub-categorized into bid-ask spread measures, price measure (share price and range of price) or return measures (i.e. intra-day return relative to number of transaction and intra-day trading 
volatility). While activity measure reflects the extent (magnitude) of trading activities. It can also be sub-categorized based depth measure (e.g. bid depth and ask depth); volume measures (i.e. number of share traded and dollar volume of share traded) and size measures (i.e. market capitalization and turn over rate). There is a general consensus that liquidity inclines when friction measure decrease and activity measure increase. Therefore, this study aims at examining whether or not liquidity or any other factors provide any explanation for cross-sectional variation in stock returns in Malaysian Capital Market. The rest of paper is organized as follow. Section one describes the fundamental feature of this study while section two discuss the literature on various forms of liquidity measures and it's impact on cross-sectional variation in stock returns. While section three discusses the methodology used to describe the relationship between stock expected returns and liquidity factors, momentum factors and Fama-French factors. And the last two sections discuss the findings and conclusion.

\section{Literature Review}

There is mounting evidence that relative stock returns can be predicted by the factors other than the risk that are inconsistent with accepted paradigms of modern finance. Jegadeesh and Titman (1993), show that the returns history of the stock is useful in predicting relative returns. In addition Fama and French (1993) \& Lakonishok et. al. (1994) show that future returns can be predicted by the relative size of the current market price of a stock and current value of the accounting numbers such as book value or earnings per share.

However, there are others who strongly believed that the findings presented by these researchers would have been flawed or spurious or at least in part. Khothari, et. al. (1995) \& Brown et.al., (1995) offered different explanation as they cited the survival bias as a problem that can aggregate predicting power.

Several finance theories advocate the ability of investors to trade any number of securities without affecting the price in fairly efficient market. However, in real context this is not the case as trading activities are subject to various restriction such as trading cost, short sales and many more that impact price formation. The influence of the market imperfection (anomalies) on security pricing has long been recognized. The liquidity in particular has attracted a lot of attention from various quarters (Chrdia, Sarkar and Subrahmanyam (2002).

The mother of modern asset pricing is depicted by Capital Asset pricing model (CAPM) has been pioneer in determining the asset pricing solely based on market factor. However, it is a question whether market factor alone can be a source of determining the asset pricing. If it were not, would the liquidity may shed some light on asset pricing? By using CAPM Fouse (1979) found that liquidity grouping could effect security selection. His work implied that stock that previously appeared attractive when single liquidity grouping was used might not appear attractive when sorted into liquidity grouping. Many recent research papers also examine the effect of liquidity on stock return using various measures of liquidity.

James and Edmister (1983) found no significant difference between the mean returns of the highest and lowest quartile trading activity portfolio. The liquidity was proxied by daily trading volume. Amihud and Mendelson (1986) found that the expected returns are increasing and concave function of liquidity as measured by relative bid-ask spread using both ordinary and generalized least square regression on NYSE stocks. While Breannan et al . (1998) evidenced a strong negative relationship between stock returns and liquidity after risk adjustment and controlling for Fama-French factors (market to book, firms size, dividend yield, stock price). On the other hand Hameed and Ting (2000) found positive relation between returns predictability and the level of liquidity. The liquidity in their study was measured by average daily trading volume, percentage of days stocks traded and frequency of trading using contrarian investment portfolio methodology on Malaysian Market.

Obviously liquidity influence stock returns however, its ability to explain stock returns remain elusive. Generally, volume has probably been most widely used proxy to explain the price changes. One of the primary focuses of price prediction is volume of trading. On the basis of stock price data from 1965 through 1977, Touhey (1980) found neither the most basic nor the most complex volume indicators have actually forecast the S\&P 500, the market consistently lead the volume rather than vice versa. Furthermore, the relationship among firm's size, liquidity and returns were analyzed by James and Edmister (1983) and suggested that a liquidity premium does not exist for inactively traded common stocks and firm's size effect is not attributable to trading activity. In addition Hammeed and Ting (2000) who documented positive relationship between trading activity and contrarian profit also showed that the different profitability of high volume and low volume portfolio is not totally due to the firm's size effects although differences are pronounced in the small firms' portfolio.

It also worthy to note that, the level of liquidity affect asset returns, while it is important to suggest that the second moment of liquidity proxy by standard deviation and coefficient of variation of both dollar trading volume and turnover could be positively related to asset returns. However, the concept was not apparently supported by Chordia et al. (2001). They document a negative relationship between average returns and coefficient of variation of both dollars trading volume and share turn over. Though numerous evidences were documented on the relationship between liquidity and 
stock returns, so far no conclusive evidences were presented. Therefore, this paper aims at examining whether the trading activity could provide an alternative explanation to cross-sectional variation in stock return in Malaysian market.

A large literature on the relationship between trading activities and stock market returns have been documented (Benston and Hagerman, 1974; Gallant, Rossi and Tauchen, 1992; Hiemstra and Jones, 1994' Lo and Wang, 2000. Foster and Vishwanathan (1993) examine the patterns in stock market trading volume, trading cost and return volatility using intraday data from a single year, 1988. For actively traded firms, they find that trading volume is low and adverse selection costs are high on Monday.

Amihud and Mendelson (1986) demonstrated that common stock with lower liquidity yielded significantly higher average return after controlling for risk and other factors. While Amihud et. al. (2000) provided theoretical argument to show how liquidity impacts financial market prices. Jones (2001) and Amihud (2002) show that time series expected return is an increasing function of liquidity that is proxied by turnover. Pastor and Stambaugh (2001) find that expected returns are cross-sectionally related to liquidity risk Amihud and Mendelson (1986) illustrate that the relative spread on stocks is negatively correlated with liquidity characteristics such as trading volume, the numbers of share outstand, number of market markers trading the stock and the stock price continuity. They also demonstrated the important of market microstructure factors as determinants of stock returns.

The bid and ask spread as used by Amihud and Mendelson (1986) is now a well-established measure of liquidity and transparency in the market. Market volatility as measure by the absolute value of the contemporaneous market return is positively associated with changes in spread (Cordial et al. (2001)), market returns are negatively associated with changes in spread. While, Brennan, Chordia and Subrahmanyam (1998) demonstrate a negative relation between average returns they use trading volume to proxy for liquidity. Brennan and Subrahmanyam (1996) find that the trading volume is an important determinant of the measure of liquidity. Chordia et. al. (2000) documented a strong cross-sectional relationship between dollar trading volume and various measure of bid-ask spread and market debt.

\section{Data Methodology}

A sample of 174 firms was selected randomly, which met the selection criteria. 72 monthly observations were drawn over the period from 1995 to 2000. Informations were extracted from the daily diary of KLSE and company annual handbook published by KLSE.

\section{Model development:}

Though various measures have been introduced, I selected dollar-trading volume as a possible proxy for liquidity since other measures, which require data that are not readily available. Two basic regressions were developed. The first model relates firms liquidity and expected return without isolating the others important variables. Therefore, in the second model I include Fama-french factors \& momentum factors that are common in cross-sectional variation in stock returns.

$$
\begin{aligned}
& \mathrm{R}=\alpha+\beta_{1} \mathrm{DOLV}+\beta_{2} \mathrm{STDDVOL}+\beta_{3} \mathrm{CVVOL}+\beta_{4} \mathrm{LIQUIV}+\varepsilon-----------(1) \\
& \mathrm{R}=\gamma 0+\gamma_{1} \mathrm{DOLV}+\gamma_{2} \mathrm{STDDVOL}+\gamma_{3} \mathrm{CVVOL}+\gamma_{4} \mathrm{BM}+\gamma_{1} \mathrm{PRICE}+\gamma \mathrm{CRT} 23+\gamma_{6} \mathrm{CRT} 46+\varepsilon----(2) \\
& \mathrm{R}=(\mathrm{Pt}-\mathrm{Pt}-1) / \mathrm{Pt}-1 \\
& \mathrm{E}(\mathrm{R})=1 / \mathrm{N} \sum \mathrm{Rt} \\
& \mathrm{VOL}=\text { the natural logarithm of the average dollar vole of trading volume in } 72 \text { month. } \\
& \mathrm{STDV}=\text { the natural logarithm of the standard deviation of dollar trading volume } \\
& \mathrm{CVVOL}=\text { coefficient of the variation of the dollar trading volume }
\end{aligned}
$$

LIQUIV = is a dummy variable that take a value of one if the average dollar volume exceed the mean to proxy for the level of liquidity. This is done to examine whether level of liquidity will have any impact on cross-sectional variation in stock return.

SIZE $=$ the natural logarithm of market value of equity of the firms.

$\mathrm{BM}=$ the natural logarithm of book value to market value ratio measured by the ratio of the book value of equity plus differed taxes to market value of equity

CRT23 = cumulative return over 2 months endings at the beginning of previous month.

CRT46 = Cumulative return over 3 month ending 3 moths previously.

\section{Hypotheses}

This study hypothesizes the liquidity, momentum factors and Fama-Frech factors do not prove any explanation for cross-sectional variation in stock returns. More specifically, following hypotheses were developed. 
Ha1: Liquidity factor measured by trading volume, volatility of trading volume and coefficient of variance in trading volume will have important impact on firms' returns as liquidity and volatility closely proxy the level of uncertainty face by the firms hence its impact on cross-sectional variation in stock returns.

Ha2: while liquidity may have important impact on firms' expected return, given nature of Malaysian capital market, firms' returns could also be partly explained by momentum factors and fama-french factors. Its is because, Malaysia capital market is relatively less efficient compare to other developed markets, hence these factors may provide significant importance to the cross-sectional variation in stock returns.

\section{Findings and Discussions}

\section{Insert Table 1 Here}

Table 1 presents the findings from multiple regressions developed based dollar volume as the basic measure for liquidity. The model includes 4 variables including a dummy variable that take a value of one if the average dollar volume exceed the mean to proxy for the level of liquidity. The model retained only 2 variables namely dummy variable and dollar-trading volume abbreviated by DVOL, are significant at the conventional level. The model can explain $8.7 \%$ of the variation in firms' expected returns. The coefficient sign for dummy variable is as expected and this is in conformity with the liquidity theory that high liquid firms are relatively less risky hence resulting lower expected returns. And no sign of autocorrelation problem is observed, as the D.W test of 2.0399 indicates no such problem.

\section{Insert Table 2 Here}

Table 2 presents a more rigorous analysis of liquidity and expected returns by controlling Fama-French factors and momentum variables. The liquidity measure was based on dollar volume. Consistent with the findings presented in previous table, dummy variable reflecting the level of liquidity turnout to be negatively and significantly related to firms' expected returns. Momentum variables proxying for 2-months cumulative relative returns prior to one month period appears to provide better prediction for firms' expected returns. Similarly, Fama French factor namely book to market value ratio abbreviated by BM provides similar explanation for the changes in firms' expected returns. Therefore, we cannot safely conclude that liquidity is only factors that matter for cross-sectional variation in firms' expected return. Though no clear cut evidence was observed on the effect of liquidity on expected returns, 98 percent of the variation in expected was explained by variables included in the second model.

\section{Conclusions}

In this study I use trading volume as a possible liquidity proxy. The study is based on a sample of 174 firms, which are selected randomly over a period from 1995 to 2000 . Monthly observations were used to examine the liquidity effect on stock expected returns. Two multiple regressions are developed separately to examine the relationship between liquidity and expected returns. The first model includes only liquidity factors while second model includes liquidity factors, momentum factors and Fama-French factors. Based on findings it is appeared that level of liquidity does matter in explaining the expected stock returns. While Fama-french factor proxied by book to market value ratio provides an important explanation for the cross-secitonal variation in stock returns. None of the second moment variables proxying liquidity appeared to be statistically significant. However, momentum factor appeared to be persistently explaining the cross-sectional variation in stock returns. The results are consistent with the study done by Amihud and Mendelson (1986) who demonstrated that common stock with lower liquidity yielded significantly higher average returns after controlling for risk and other factors. Hence the findings implies that the portfolio managers who tailor their portfolio on the basis of liquidity should be extra cautious as the liquidity is not only the factors that determine the cross-sectional variation in stock returns in Malaysian capital market as the momentum and Fama-French factors provide possible explanation for cross-sectional variation in stock returns.

\section{References}

Amihud V. (2002). Illiquidity and Stock Returns: Crossectional and Time series Effect, Journal of Financial Market, 5 , pp.31-56.

Amihud, Y. \& Mendelson, H. (1986). Asset pricing and the bid-ask spread. Journal of Financial Economics, 17. pp223-249.

Brennan, M.J. \& Subrahmanyam. (1996). Market Micro-structure and asset pricing: on the compensation for liquidity in stock returns, journal of financial economics, 41, 441-464

Brennan, M.J., Chordia, T. \& Subrahmanyam, A. (1998). Alternative factor Specifications, security characteristics and the cross-sectional of expected stock returns. Journal of Financial Economics, 49, 345-373.

Brown, S., W. Goetzmann \& S. Ross. (1995). Survival, Journal of Finance 50,pp. 853-873.

Chordia, T., Shivakumar, L. \& Subrahmanyam, A. (2000). The cross section of dailyvariation in liquidity. http://www.london.edu/faculty/1shivakumar/css51.pdf. Accessed On $8^{\text {th }}$ October, 2001.

Chordia, T., Subrahmanyam, A. \& Anshuman, V.R. (2001). Trading activity and Expected returns. Journal of Financial Economics, 59. pp3-32. 
Edmister, Robert O. \& Christopher James. (1983), Is Illiquidity a Bar to Buying Small Cap Stocks?, Financial Analysts Journal, pp. 14-19.

Fama, E.F. \& Frnch, K.R. (1993). common risk factors in the returns on stocks and bond., journal of financial economics 33, 3-56

Foster, F. \& S. Viswanathan. (1993), Variations in trading volume, return volatility \& trading costs: Evidence on recent price formation models, Journal of Finance, 48, 1, 187-211.

Gallant, A., P.Ross \& GTauchen, (1992). Stock Price and Volume, Review of Financial Studies, 79. 151-242

Hammed, A. \& Ting, S. (2000). Trading volume and short-horizon contrarian profits: evidence from the Malaysian market. Pacific-Basin Finance Journal, 8, 67-84.

Hiemstra, C. \& J.D. Jones, (1994). Testing for linear and non-linear Granger causality in the stock price-volume relationship, Journal of Finance, 49, 1639-1664.

James, C. \& Edmister, R.O. (1983). The relation between common stock returns trading activity and market value. Journal of Finance, 4(38), .1075-1086.

Jones C. (2001). A Century of Stock Market Liquidity and Trading Cost, Working paper, Columbia University, NY.

Kothari, S.P., Shanken, J. \& Sloan, R.G. (1995). Another look at the cross-section of expected stock returns, Journal of Finance, 50, 185-224.

Lakonishock, J., Shleifer, A. \& Vishny. R.W. (1992). The Impact of Institutional Trading on Stock Price, Journal of Financial Economics, August, pp.23-43

Lo A. \& J. Wang. (2000). Trading Volume, Definition, Data Analysis and Implication of Portfolio Theory, Review of Financial Studies, 13,pp.257-300

Pastor, L. \& Stambaugh R. (2003). Liquidity risk and expected stock returns. Journal of Political Economy, 111, 642-685.

Touhey, John C. (1980). Stock market forecasting for alert investors. New York: AMACOM.

Table 1. regression results for first model

\begin{tabular}{|l|l|l|l|}
\hline Variables & Coefficient & T-value & P-value \\
\hline C & -.0156 & -1.98 & $.048^{* *}$ \\
LIQUIV & -.00547 & -2.453 & $.0163^{* *}$ \\
DVOL & .003658 & 3.4508 & $.0007^{* * *}$ \\
STDVOL & -.00114 & -.5260 & .5996 \\
CVVOL & .01035 & 1.415 & .1588 \\
\hline R-Square & .0871 & \\
F-Value & $4.033^{* * *}$ & \\
DW & 2.03 & & \\
$* * *$ Significant at $1 \%$ level & $* *$ Significant at $5 \%$ level & \\
\hline
\end{tabular}

Table. 2 Regression results for Second Model

\begin{tabular}{|l|l|l|l|}
\hline Variable & Coefficients & T-value & P-value \\
\hline C & .001907 & 1.088 & .278 \\
Size & .000317 & .267 & .790 \\
BM & .000324 & $1.9348^{*}$ & .055 \\
LIQUIV & -.000593 & $-2.041^{* *}$ & .0469 \\
DVOL & -.00146 & -.883 & .3785 \\
STDVOL & -.000324 & -1.094 & .294 \\
CVVOL & -.00114 & -1.1324 & .2591 \\
CRT23 & .5759 & $19.33^{* * *}$ & .0000 \\
CRT46 & -.0448 & $-1.75^{*}$ & .081 \\
\hline R-square & .985 & \multicolumn{2}{|c|}{} \\
F-value & $11.431^{* * *}$ & \\
D-W & 1.741 & *significant at $10 \%$ level
\end{tabular}

